\title{
PASSIVE CONTROL OF STRUCTURES USING SLIDING ISOLATORS AT INTERMEDIATE FLOOR LEVELS
}

\author{
Amit J. Thoriya ${ }^{1}$, Mazhar A. Dhankot ${ }^{2}$ \\ ${ }^{1}$ PG Student, Civil Engineering Department, MEFGI, Rajkot, Gujarat, India \\ ${ }^{2}$ Assistant Professor, Civil Engineering Department, MEFGI, Rajkot, Gujarat, India
}

\begin{abstract}
Base isolation or seismic isolation enables the reduction in earthquake forces by lengthening the natural time period of structure; hence it is significantly effective in low and mid-rise buildings with less than 10 stories. Taller building with height more than 10 storey already have larger time period and the effectiveness of base isolation is reduced., In this paper an attempt has made to study the feasibility of sliding isolation at intermediate floor levels. Two R.C.C. building 12 storey and 18 storey are analyzed by dividing each building into different segment and each segment is isolated with Friction Pendulum isolators. The response of structure with isolators at multiple floor levels are studied with 1940 El Centro, 1994 Northbridge and 1995 Kobe time-history and responses are compared to the conventional fixed base structure and with structures isolated at base. Considerable reduction is observed in the building isolated at intermediate floor level.
\end{abstract}

Keywords: Base isolation, friction pendulum system, time history, segmental buildings. $* * *$

\section{INTRODUCTION}

Base isolation has been recognized as one of the effective passive control technique to reduce the earthquake forces. Base isolation is the technique which decouples the building or structure from the horizontal components of the ground motion by interposing the structural element with low horizontal stiffness between structure and foundation [1]. Base isolation enables the reduction in earthquake forces by lengthening the time-period of structure. Base isolation is quite effective in buildings which have lower natural timeperiod i.e. generally buildings with height less than 10 stories. Buildings with more than 10 stories or 15 stories already have contained the larger time period and not needed to be isolated. Taller buildings are already flexible in nature and after application of base isolation flexibility increase much more. Hence it attracts less earthquake forces than stiff buildings. But in taller building there is enough deformation available which may lead to damage of structure and non-structure components of building, and therefore some technique must be used to control the structure. One technique may be concept of segmental building in which the building or structure is divided in different segment and each segment is isolated. In this paper attempt is made to investigate the feasibility of sliding isolation with friction pendulum at intermediate floor level. The 12 storey and 18 storey R.C.C. buildings are divided into different segment and isolated. Non-linear time history analysis is carried out for 1940 El Centro, 1994 Northbridge and 1995 Kobe earthquake time history by using SAP 2000.

\section{ANALYTICAL MODEL}

RCC structures taken for the current study are 12 storey and 18 storey high. Following cases are studied to investigate the dynamic behavior of sliding isolators at intermediate floor levels.

(1) Fixed base structure (Case-A) (2) structure with all isolated at base (Case-B) (3) structure with isolators at two different levels, at base and at mid height of structure (Case-C) (4) structure with isolators at three different levels, at base and two other levels of $1 / 3$ height (Case-D). location of isolators are shown in fig1and fig2.
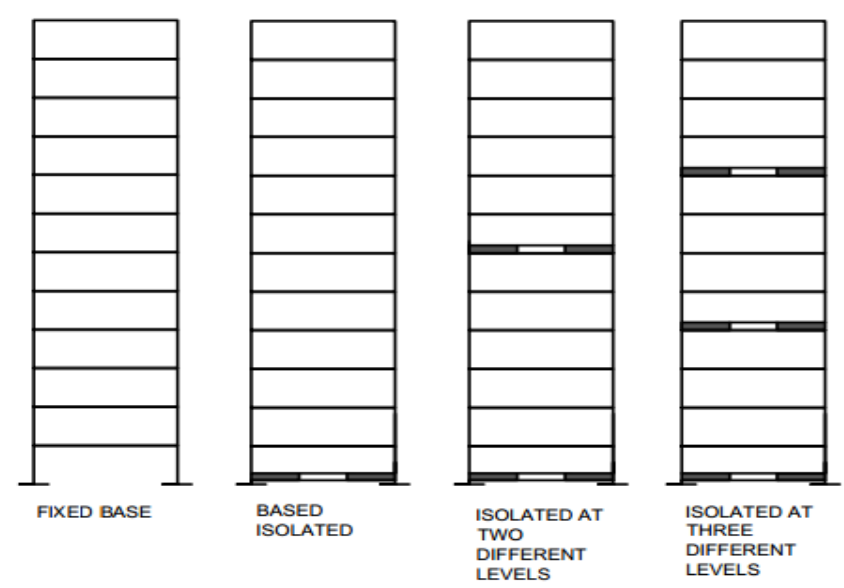

Case-A

Case- $B$

Case-C

Case-D

Fig1. Location of isolators for 12 storey building 

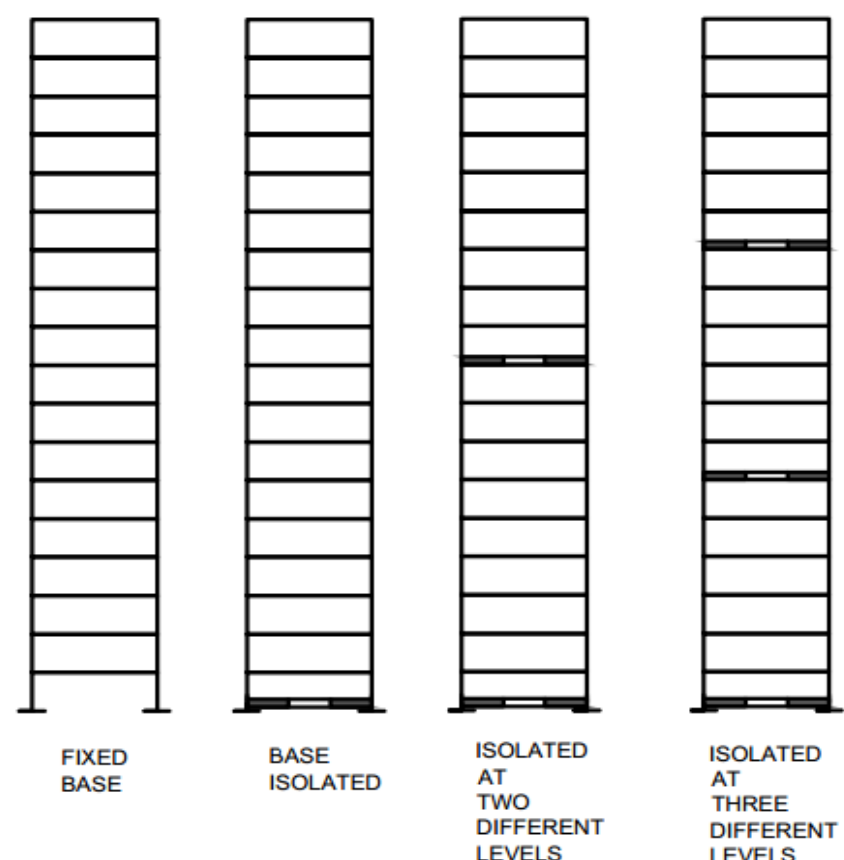

Case-A Case-B Case-C Case-D

Fig2. Location of isolators for 18 storey building

\subsection{Dimensions and Properties of Material}

\subsubsection{2-Storey Building}

This building is reinforced concrete building consisting of 3 bays in both direction as shown in Figure, the plan of the building is $18 \mathrm{~m} \times 18 \mathrm{~m}$ with storey height of $3 \mathrm{~m}$. Total height of the building is $36 \mathrm{~m}$. The thickness of slab of each floor is $150 \mathrm{~mm}$. The grade of concrete is M-30. The size of beams and columns are $0.45 \times 0.60$ and $0.6 \times 0.6$ respectively.

\subsubsection{2-storey Building}

This building is reinforced concrete building consisting of 3 bays in both direction as shown in Figure, the plan of the building is $18 \mathrm{~m} \times 18 \mathrm{~m}$ with storey height of $3 \mathrm{~m}$. Total height of the building is $54 \mathrm{~m}$. The thickness of slab of each floor is $200 \mathrm{~mm}$. The grade of concrete is M-30. The size of beams and columns are $0.8 \times 0.45$ and $0.7 \times 0.7$ respectively.

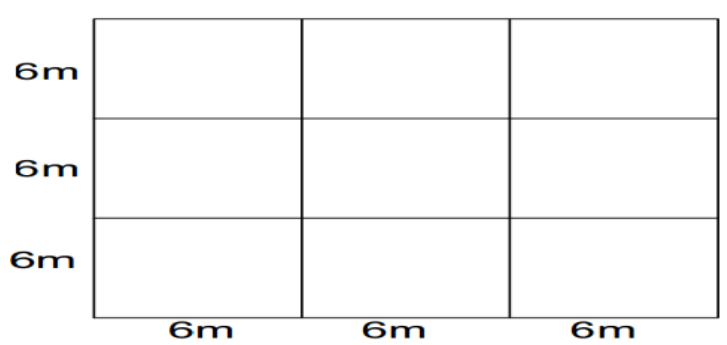

Fig3. Plan of 12 storey and 18 storey building

\subsection{Time History}

Table1. Time history

\begin{tabular}{|l|l|l|l|l|}
\hline Time history & $\begin{array}{l}\text { Earthquake } \\
\text { Magnitude }\end{array}$ & $\begin{array}{l}\text { Distance } \\
(\mathrm{km})\end{array}$ & PGA & $\begin{array}{l}\text { PGA } \\
(\mathrm{g} / \mathrm{s})\end{array}$ \\
\hline $\begin{array}{l}\text { Imperial } \\
\text { Valley, 1940, }) \\
\text { El Centro }\end{array}$ & 6.9 & 10.0 & 452.03 & 0.46 \\
\hline $\begin{array}{l}1994 \\
\text { Northridge }\end{array}$ & 6.7 & 7.5 & 851.62 & 0.87 \\
\hline 1995 Kobe & 6.9 & 3.4 & 902.75 & 0.92 \\
\hline
\end{tabular}

Source: SAC Steel Project | 1301 S. 46th Street | Richmond, CA 94804-4698 | http://www.sacsteel.org/

\section{ANALYTICAL RESULTS}

After non-linear time history analysis, following results are obtained.

\subsection{Natural Time Period}

Natural time period of 12-storey and 18-storey structure for first three modes with four different cases are shown in fig.it is observed that the time period of Case-D is highest for all modes as compared to the other Cases. It is due to the increase in number of isolators at multiple levels.

Table2. Natural Time period of 12-storey Structure (sec)

\begin{tabular}{|l|l|l|l|l|}
\hline & Case-A & Case-B & Case-C & Case-D \\
\hline Mode-1 & 1.36 & 3.45 & 4.52 & 5.45 \\
\hline Mode-2 & 1.36 & 3.45 & 4.52 & 5.45 \\
\hline Mode-3 & 1.15 & 2.98 & 3.93 & 4.75 \\
\hline
\end{tabular}

Table3. Natural Time period of 12-storey Structure (sec)

\begin{tabular}{|l|l|l|l|l|}
\hline & Case-A & Case-B & Case-C & Case-D \\
\hline Mode-1 & 1.74 & 4.65 & 6.02 & 7.18 \\
\hline Mode-2 & 1.74 & 4.65 & 6.02 & 7.18 \\
\hline Mode-3 & 1.41 & 3.90 & 5.12 & 6.14 \\
\hline
\end{tabular}

\subsection{Storey Drifts}

Considerable reduction in storey drift can be seen in structures isolated at multiple levels when compared to the structure isolated at base level. The maximum storey drift reduction with respect to fixed base structure in 12 storey is shown as $81.48 \%$ for Case-D in Kobe time history, and in 18-storey the maximum reduction is shown as $83.29 \%$ for Case-D in Northbridge time history. It is observed that when isolators are 
provided at multiple levels, there are considerable reductions in storey drift as compared to the fixed base structure as well as base isolated structures. The plots of storey drift for different cases and for different time history are shown in fig. to fig. Table 1 and Table 2 Shown the reduction in storey drift for different cases.

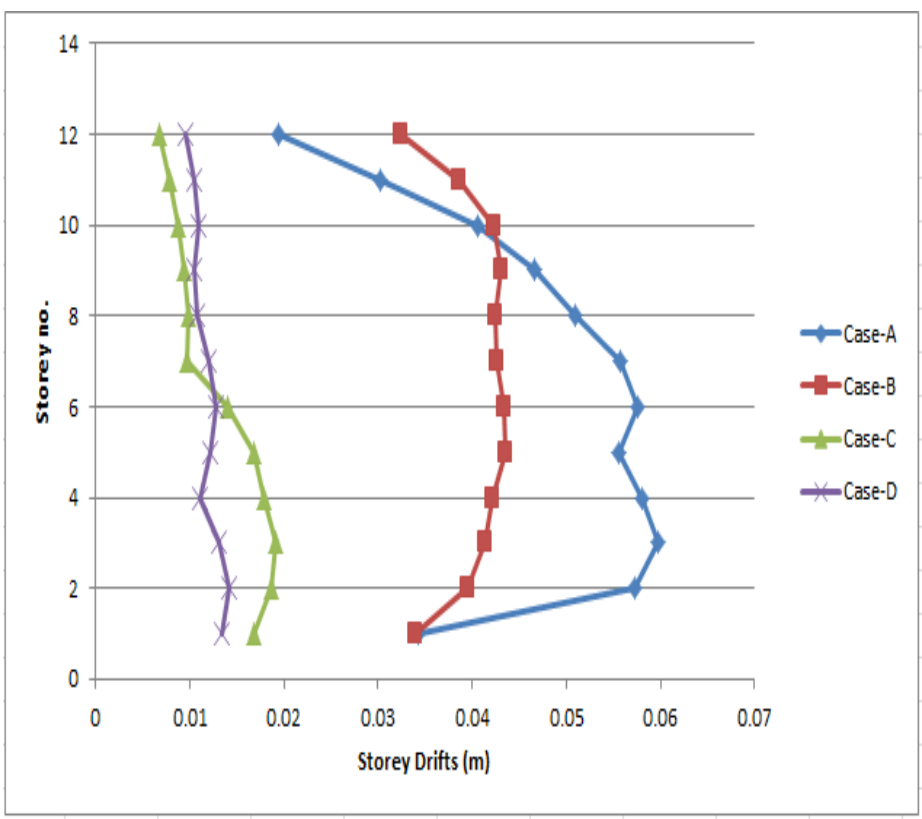

Fig4. Plot of storey drift for El Centro in 12 storey building

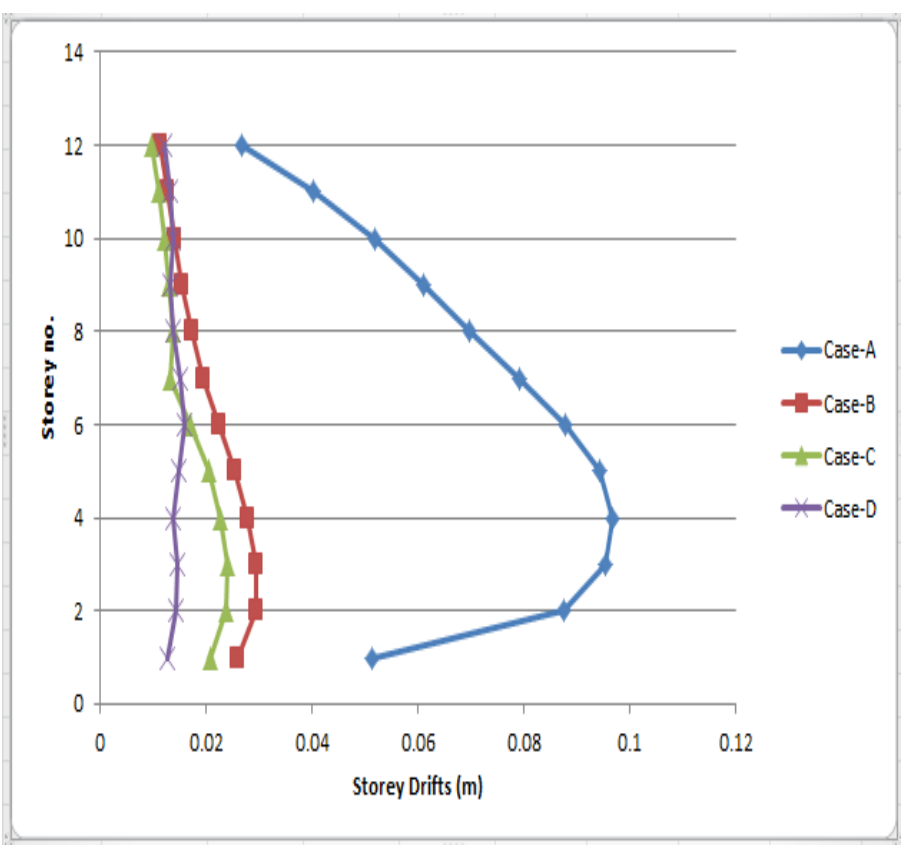

Fig5. Plot of storey drift for Northbridge in 12 storey

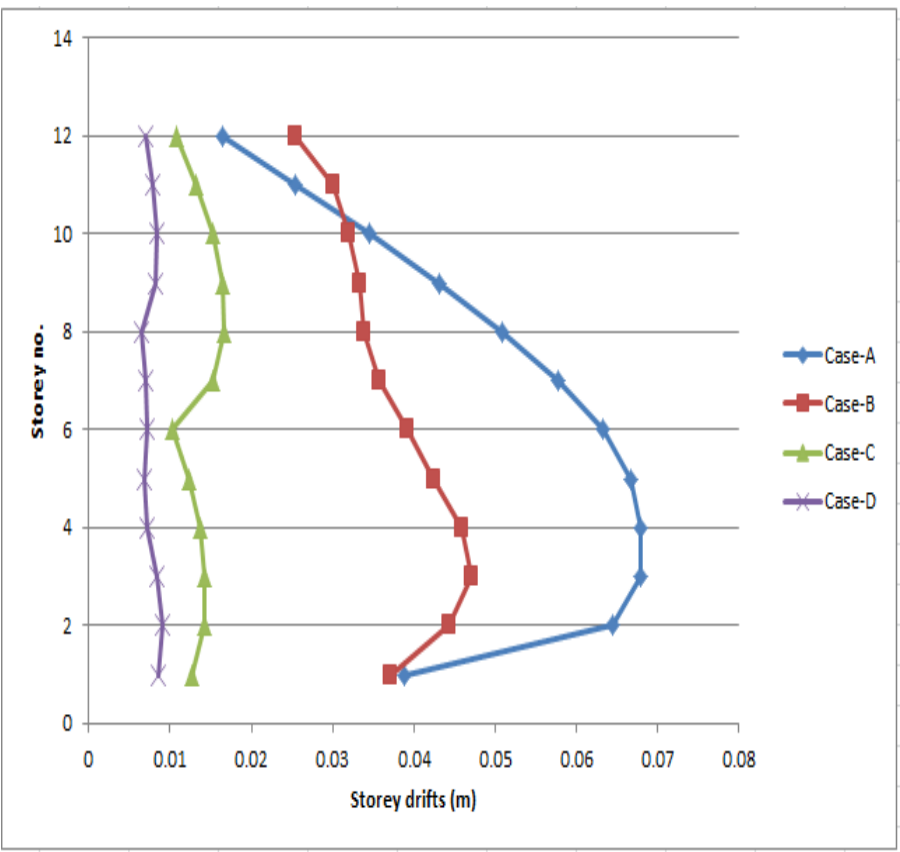

Fig6. Plot of storey drift for Kobe in 12 storey building

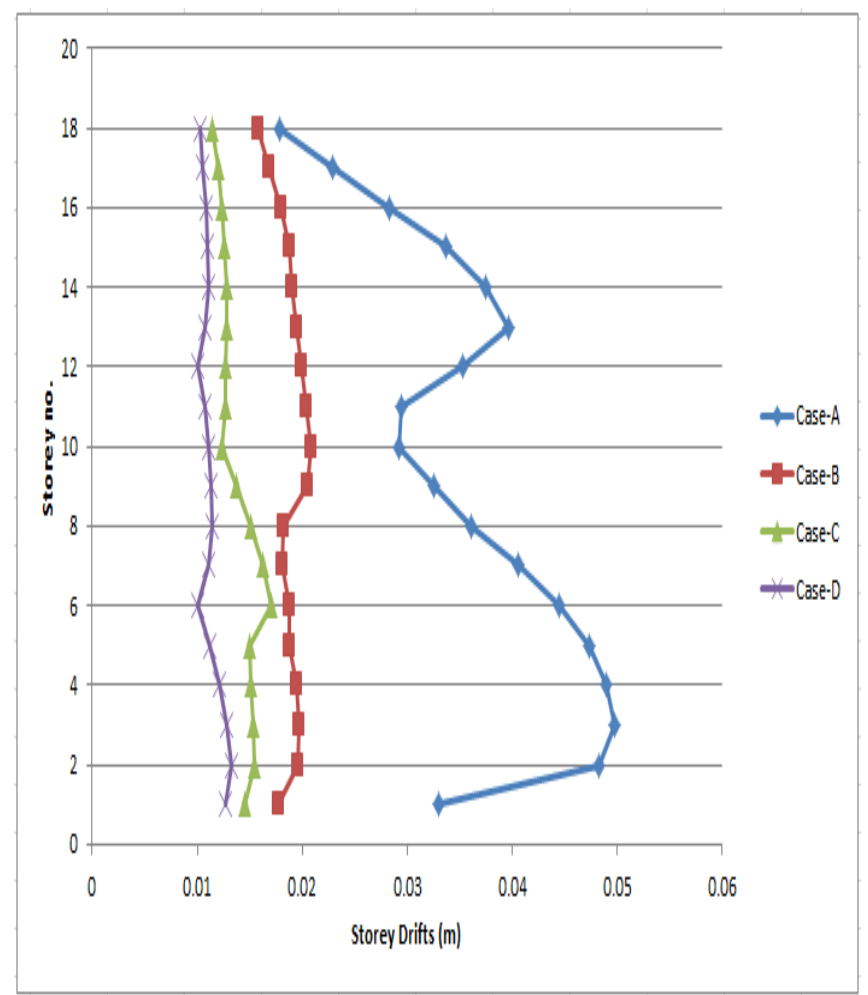

Fig7. Plot of storey drift for El Centro in 18 storey building 


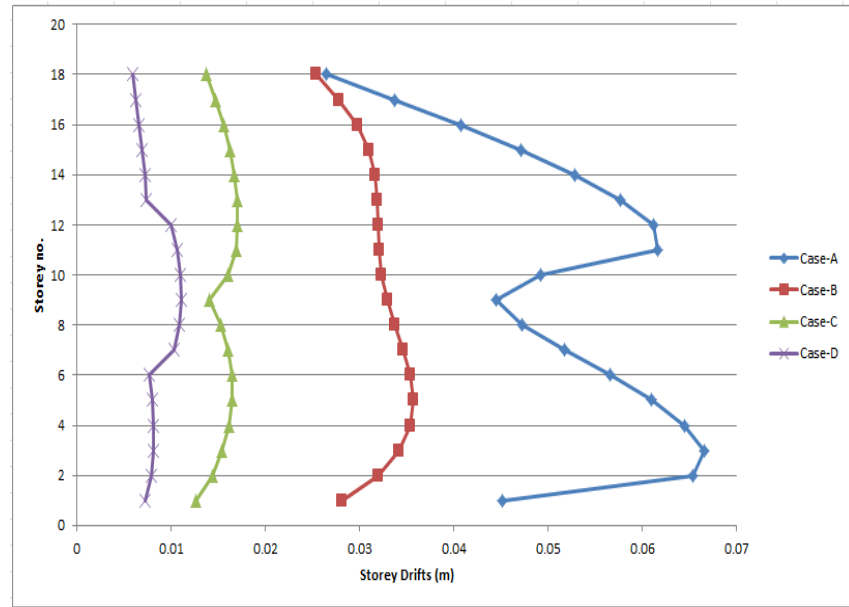

Fig8. Plot of storey drift for Northbridge in 18 storey building

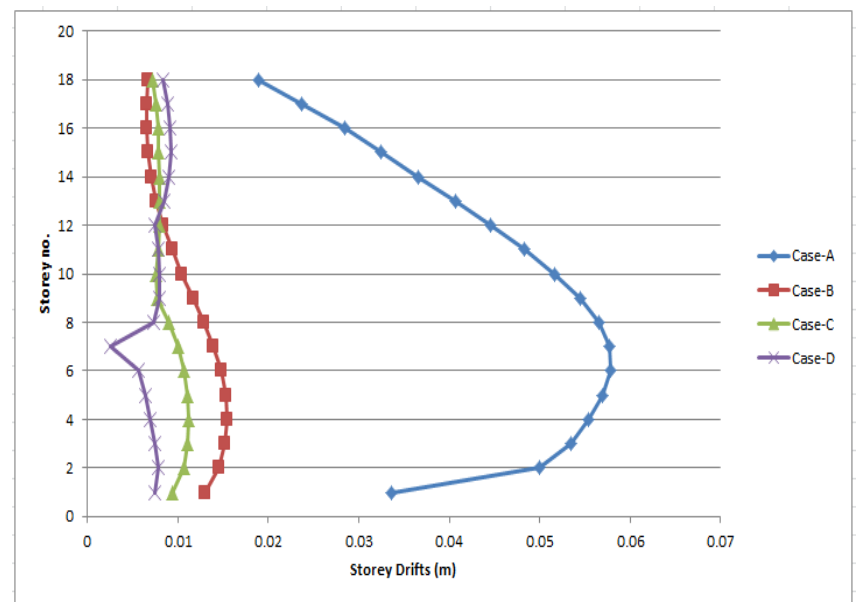

Fig9. Plot of storey drift for Kobe in 18 storey building

Table4. Reduction in Storey Drifts (\%) w.r.t Case -A (Fixed Base)

\begin{tabular}{|l|l|l|l|}
\hline & Case-B & Case-C & Case-D \\
\hline El Centro & 7.19 & 71.84 & 73.02 \\
\hline Northbridge & 69.10 & 74.94 & 77.69 \\
\hline Kobe & 16.86 & 67.48 & 81.47 \\
\hline
\end{tabular}

Table5. Reduction in Storey Drifts (\%) w.r.t Case -A (Fixed Base)

\begin{tabular}{|l|l|l|l|}
\hline & Case-B & Case-C & Case-D \\
\hline El Centro & 44.93 & 60.16 & 67.15 \\
\hline Northbridge & 35.98 & 68.58 & 83.28 \\
\hline Kobe & 75.19 & 78.52 & 80.40 \\
\hline
\end{tabular}

\subsection{Acceleration}

Acceleration of different cases are shown in fig. to fig. it is observed from the results that there are considerable reductions in acceleration as compared to the fixed base structure and structure isolated at base. The maximum reduction in acceleration in 12 storey structure as compared to fixed base is shown as $73.5 \%$ for Case-D in Northbridge time history and in 18 storey structure the maximum reduction is shown as $81.50 \%$ for Case-D in Kobe time history. The tabular comparisons of reductions in acceleration for different cases are shown in table and table.

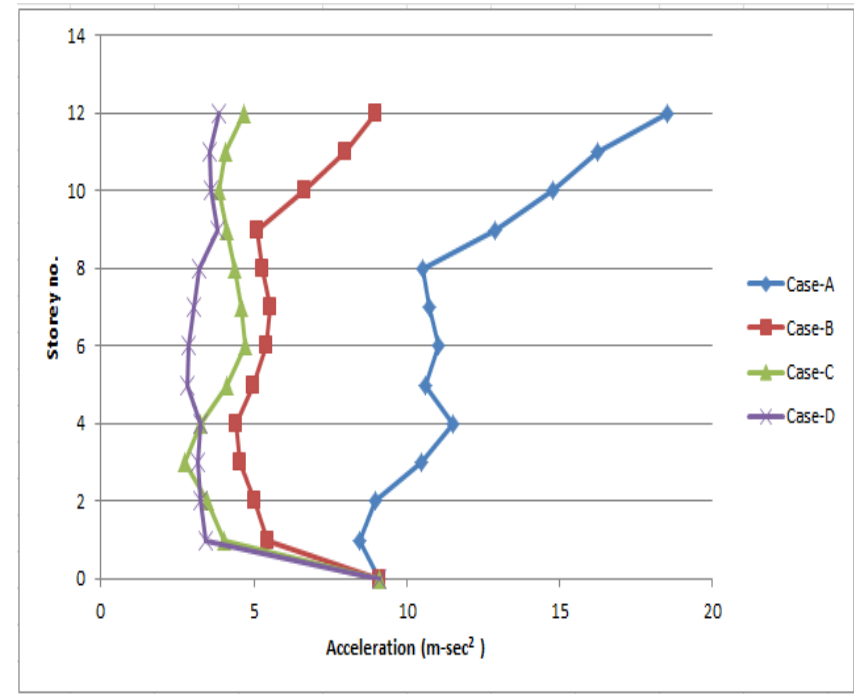

Fig10. Plot of Acceleration for El Centro in 12 storey building

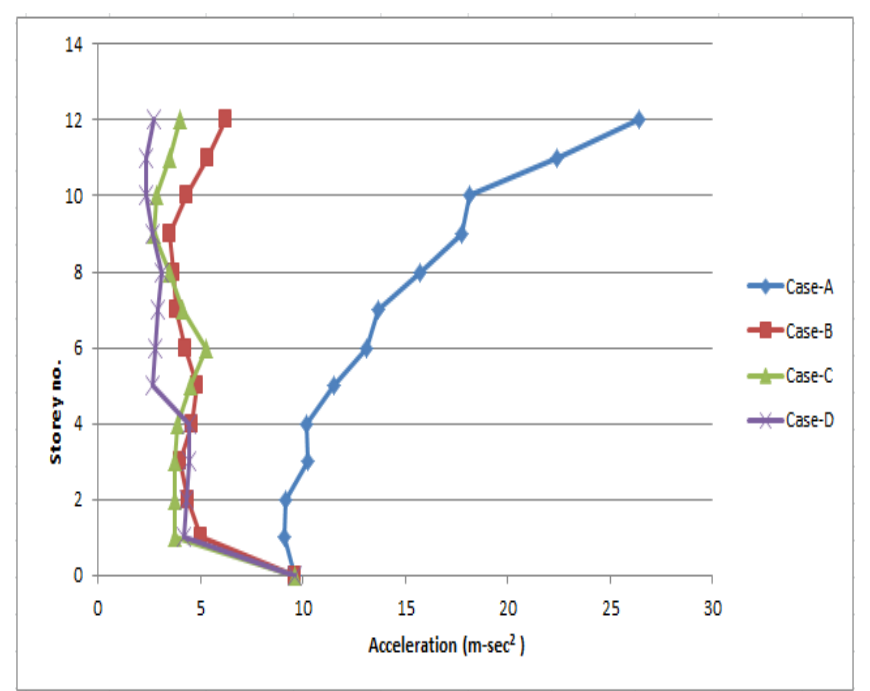

Fig11. Plot of Acceleration for Northbridge in 12 storey building 


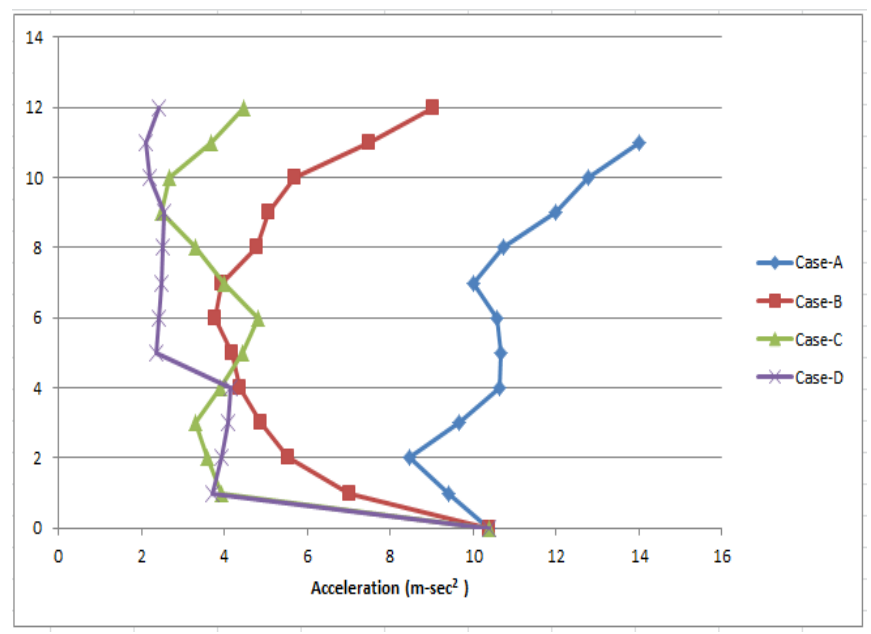

Fig12. Plot of Acceleration for Kobe in 12 storey building

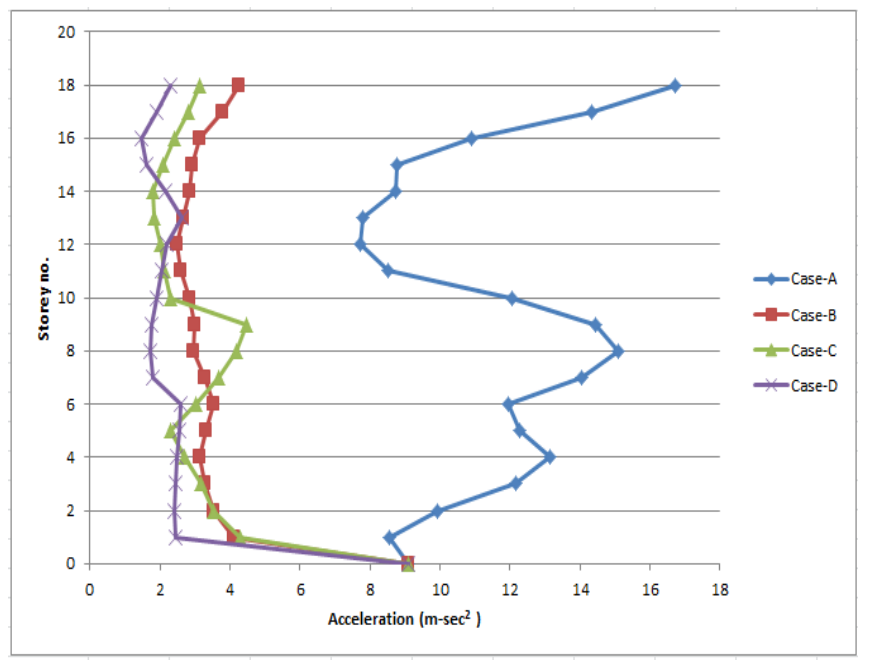

Fig13. Plot of Acceleration for El Centro in 18 storey building

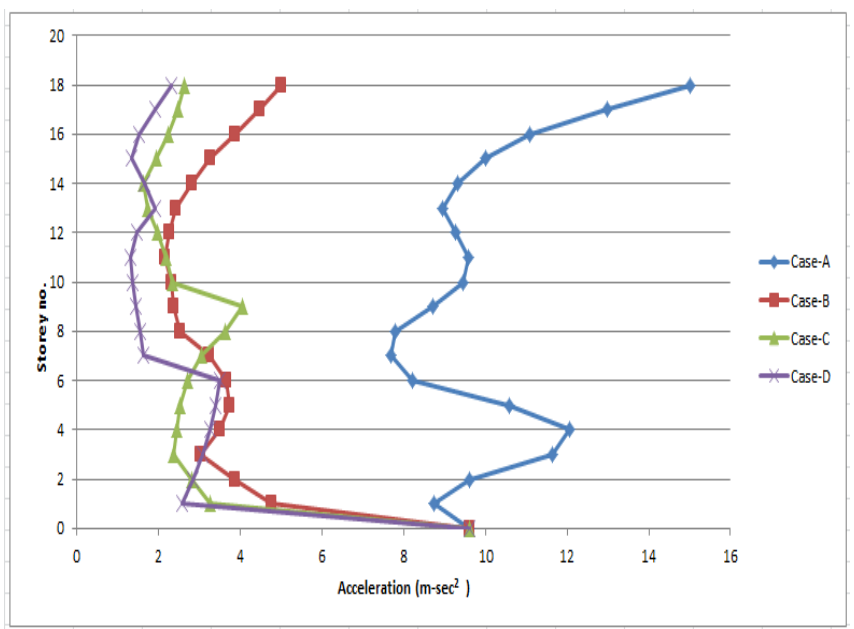

Fig14. Plot of Acceleration for Northbridge in 18 storey building

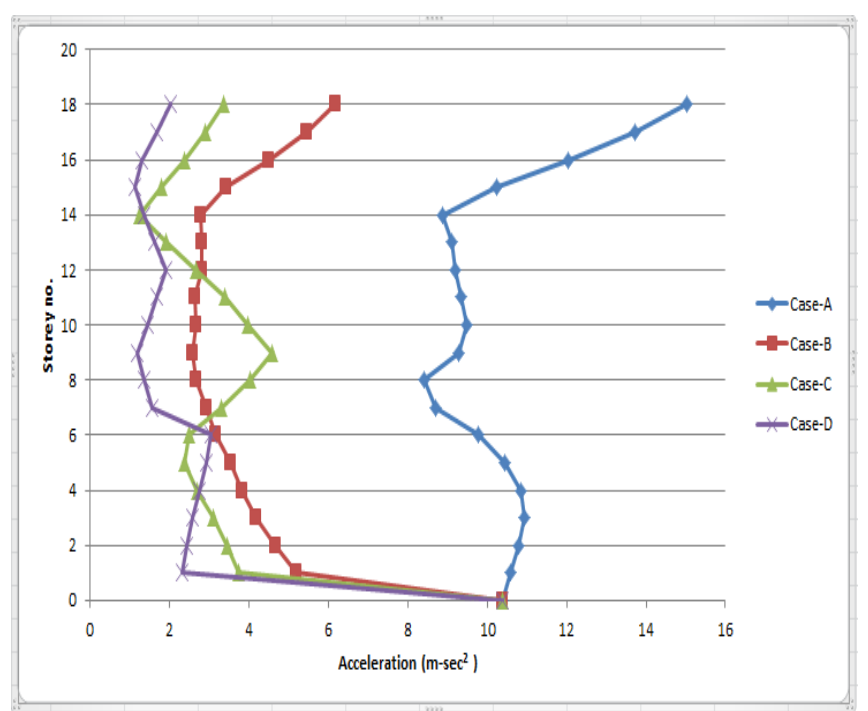

Fig15. Plot of Acceleration for Kobe in 18 storey building

Table6. Reduction in Acceleration (\%) for 12-storey w.r.t. Case-A (Fixed base)

\begin{tabular}{|l|l|l|l|}
\hline & Case-B & Case-C & Case-D \\
\hline El Centro & 51.49 & 65.39 & 71.39 \\
\hline Northbridge & 66.37 & 70.87 & 73.84 \\
\hline Kobe & 50.97 & 65.87 & 72.52 \\
\hline
\end{tabular}

Table7. Reduction in Acceleration (\%) for 18-storey w.r.t. Case-A (Fixed base)

\begin{tabular}{|l|l|l|l|}
\hline & Case-B & Case-C & Case-D \\
\hline El Centro & 71.03 & 74.46 & 80.18 \\
\hline Northbridge & 66.98 & 73.43 & 78.63 \\
\hline Kobe & 65.29 & 70.77 & 81.50 \\
\hline
\end{tabular}

\subsection{Base Shear}

The base shear charts for different cases are shown in fig. to fig. the maximum reduction in base shear for 12 storey structure as compared to the fixed base is observed as $76.6 \%$ for Case-D in El Centro time history and for 18 storey structure the maximum reduction in base shear as compared to the fixed base is observed as $80.8 \%$ for Case-D in El Centro ground motion. Tabular comparison of reduction in maximum base shear as compared to the fixed base is shown in table and table. 


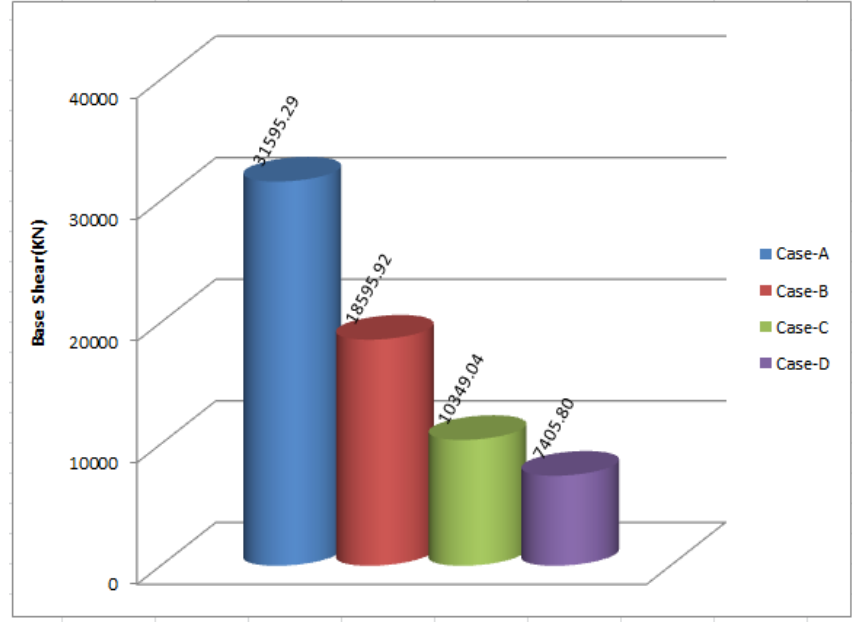

Fig16. Plot of Base shear for El Centro in 12 storey building

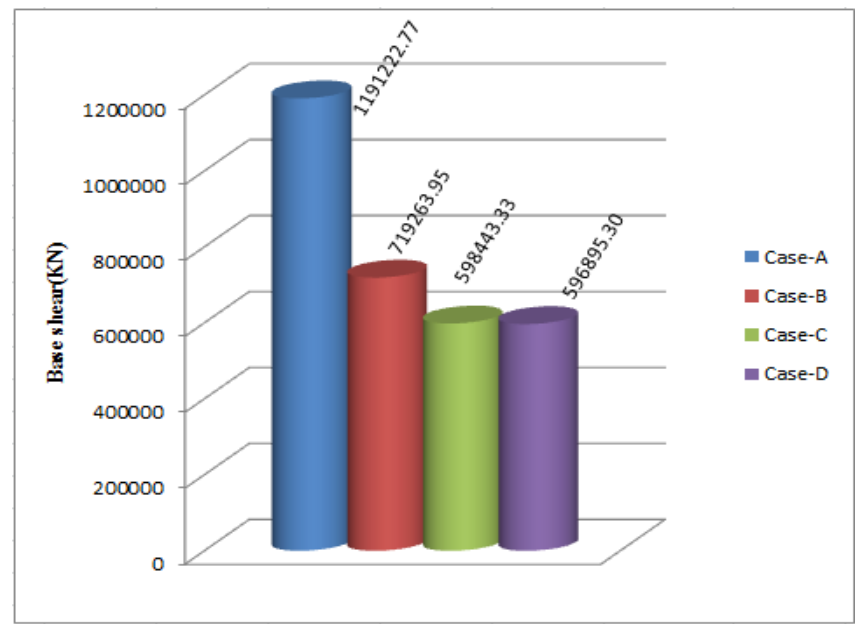

Fig17. Plot of Base shear for Northbridge in 12 storey building

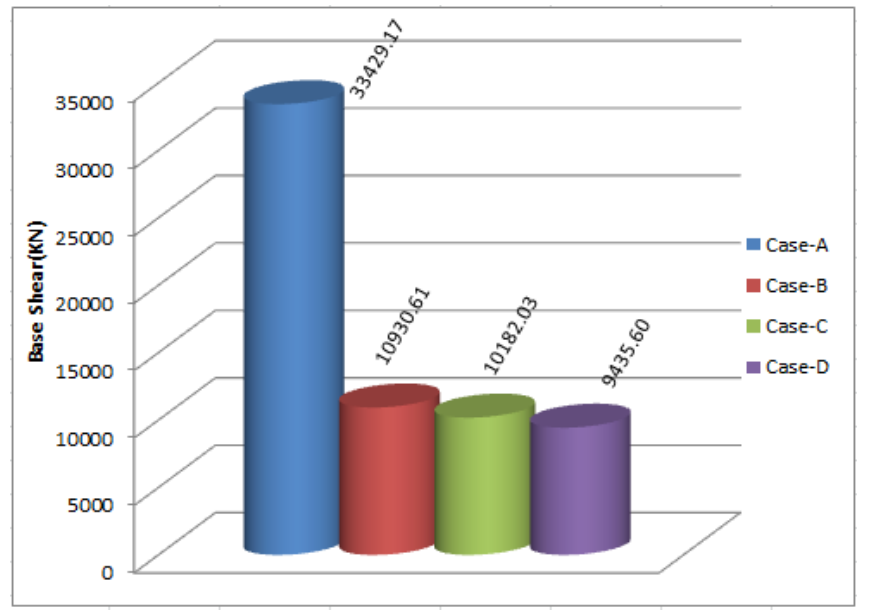

Fig18. Plot of Base shear for Kobe in12 storey building

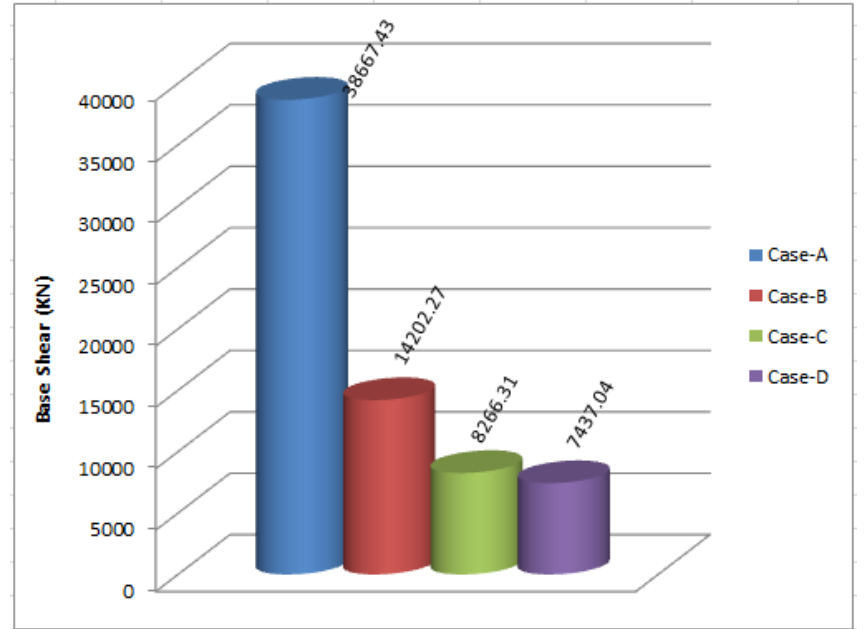

Fig19. Plot of Base shear for El Centro in 18 storey building

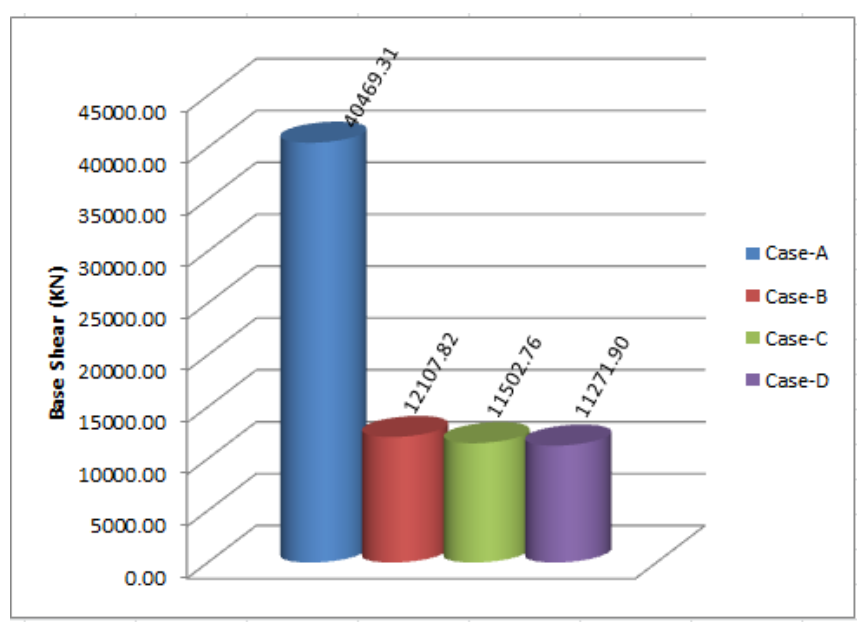

Fig20. Plot of Base shear for Northbridge in 18 storey building

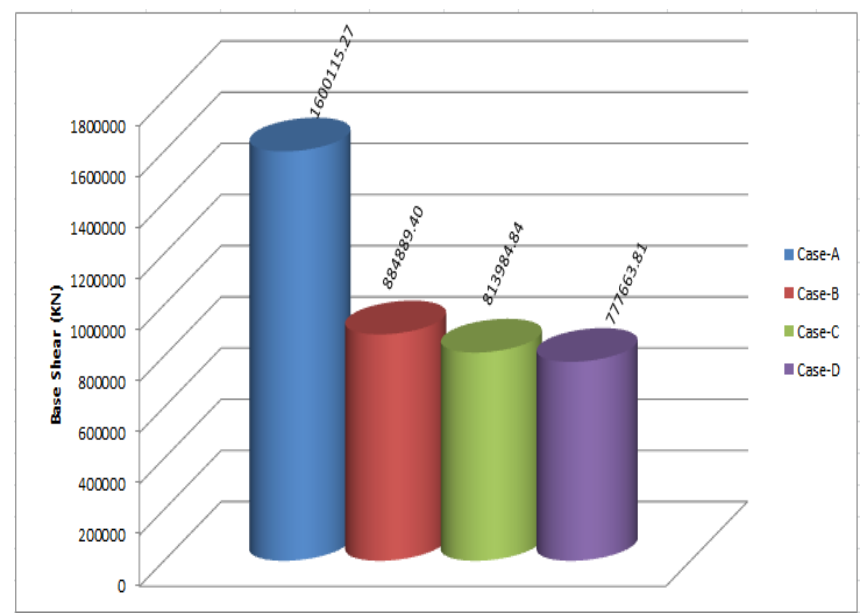

Fig21. Plot of Base shear for Kobe in 18 storey building 
Table8. Reduction in Base Shear (\%) for 12-storey w.r.t. Case-A (Fixed base)

\begin{tabular}{|l|l|l|l|}
\hline & Case-B & Case-C & Case-D \\
\hline El Centro & 41.14 & 67.24 & 76.56 \\
\hline Northbridge & 67.78 & 71.20 & 72.23 \\
\hline Kobe & 67.30 & 69.54 & 71.77 \\
\hline
\end{tabular}

Table9. Reduction in Base Shear (\%) for 18-storey w.r.t. Case-A (Fixed base)

\begin{tabular}{|l|l|l|l|}
\hline & Case-B & Case-C & Case-D \\
\hline El Centro & 63.27 & 78.62 & 80.77 \\
\hline Northbridge & 70.08 & 71.58 & 72.15 \\
\hline Kobe & 74.46 & 78.07 & 78.63 \\
\hline
\end{tabular}

\subsection{Overturning Moment}

The considerable reduction in Overturning Moment can be seen for structures isolated at multiple levels as compared to the fixed base as well as isolated at base. The maximum reduction in Overturning Moment for 12 storey structure as compared to fixed base structure is shown as $49.9 \%$ in Case-D for Northbridge time history and for 18 storey structure the maximum reduction as compared to fixed base is shown as $55.5 \%$ in Case-D for Northbridge time history ground motion. The fig. to fig. are shown the charts for Overturning Moment for different Cases. Tabular comparisons for different cases in reduction in Overturning Moment are shown in Table and Table.

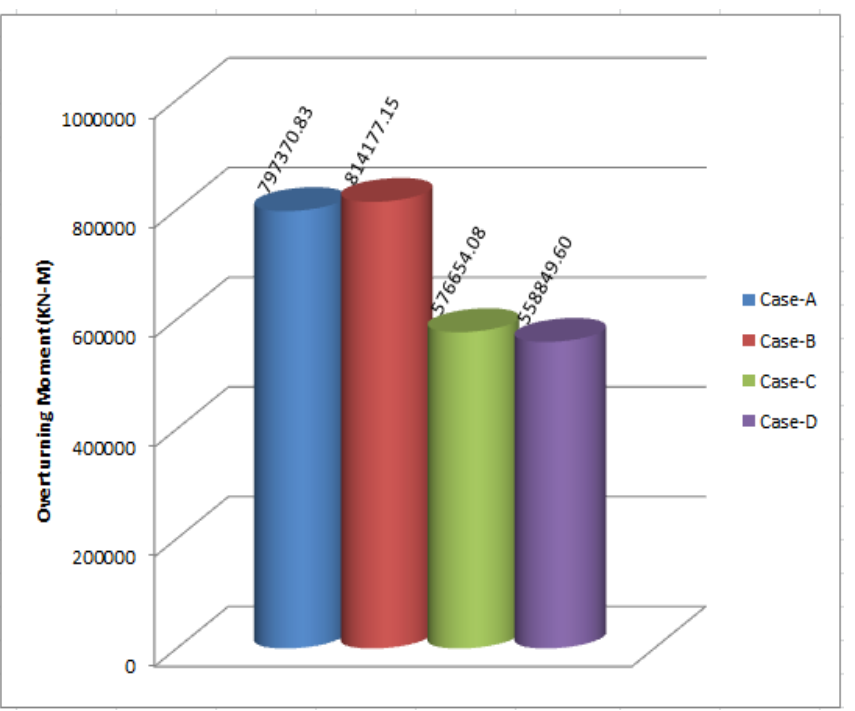

Fig22. Plot of Overturning Moment for El Centro in 12 storey building

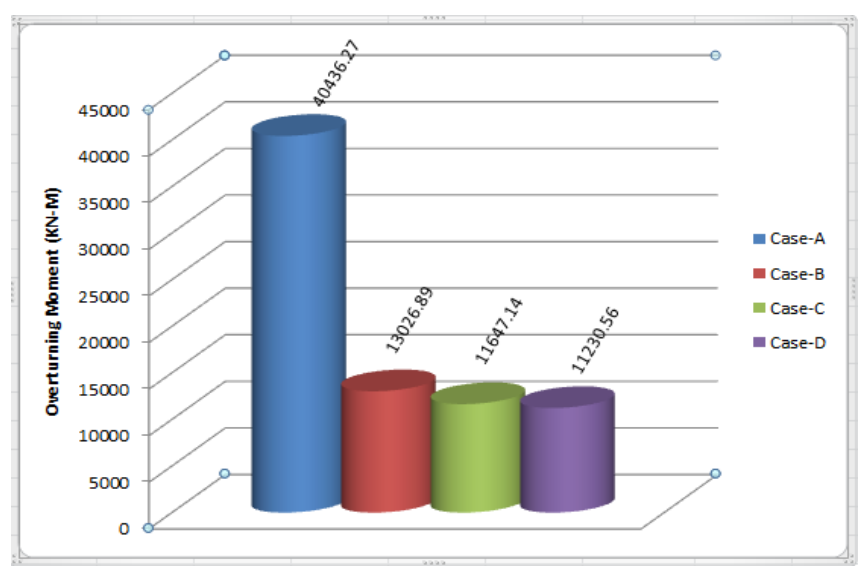

Fig23. Plot of Overturning Moment for Northbridge in 12 storey building

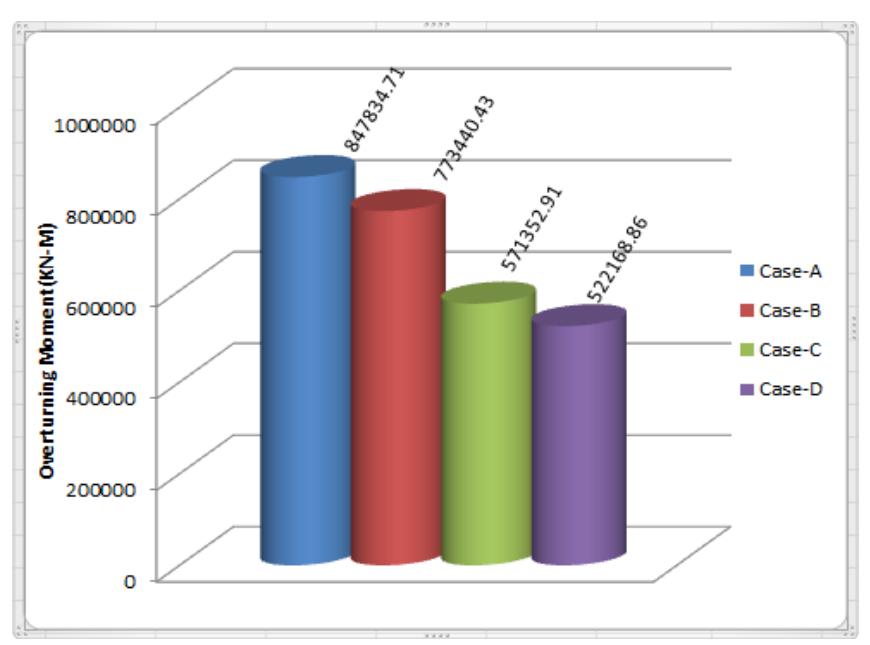

Fig24. Plot of Overturning Moment for Kobe in 12 storey building

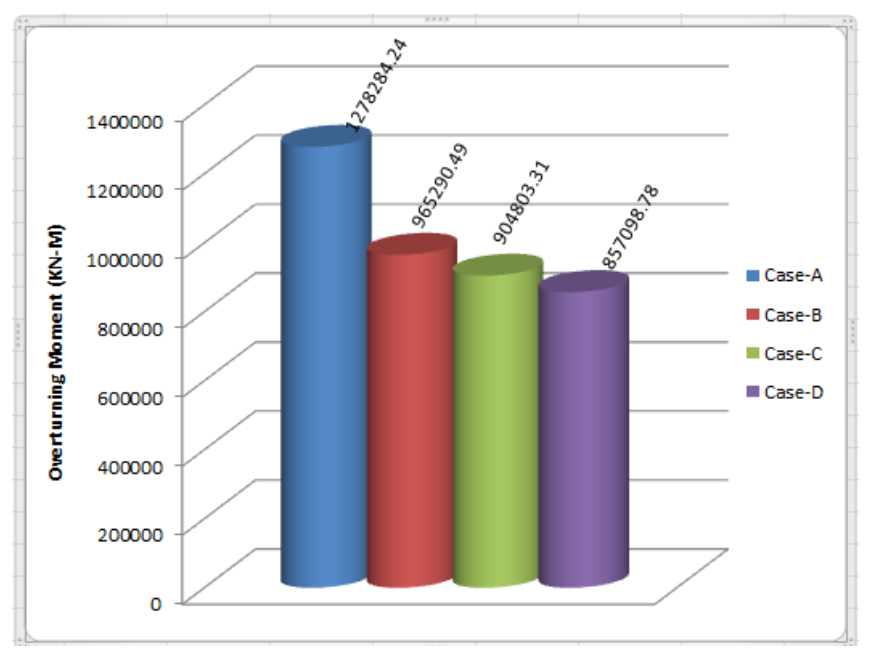

Fig25. Plot of Overturning Moment for El Centro in 18 storey building 


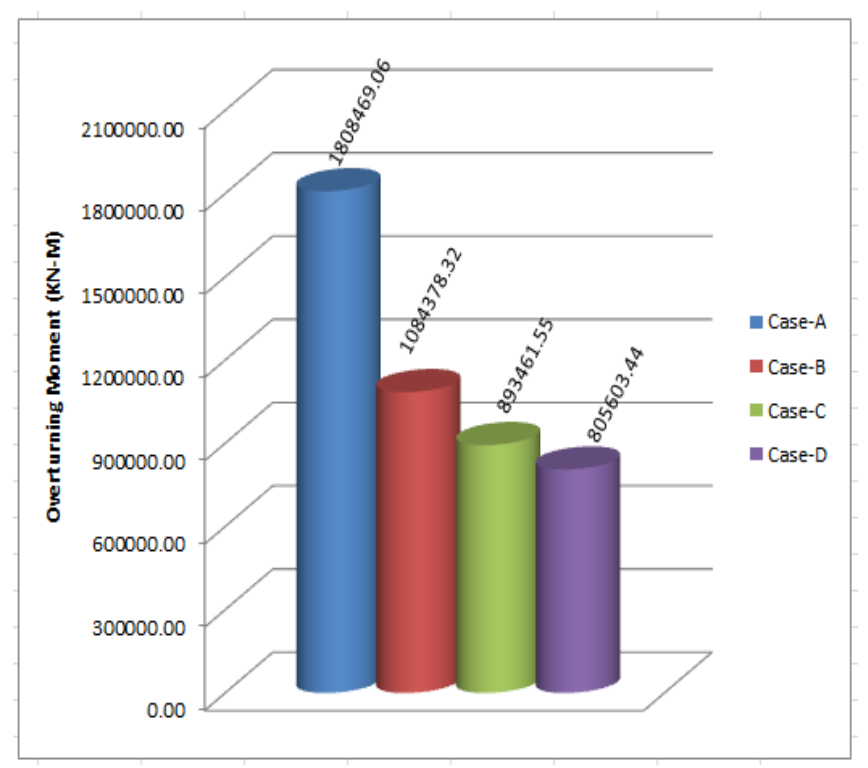

Fig26. Plot of Overturning Moment for Northbridge in 18 storey building

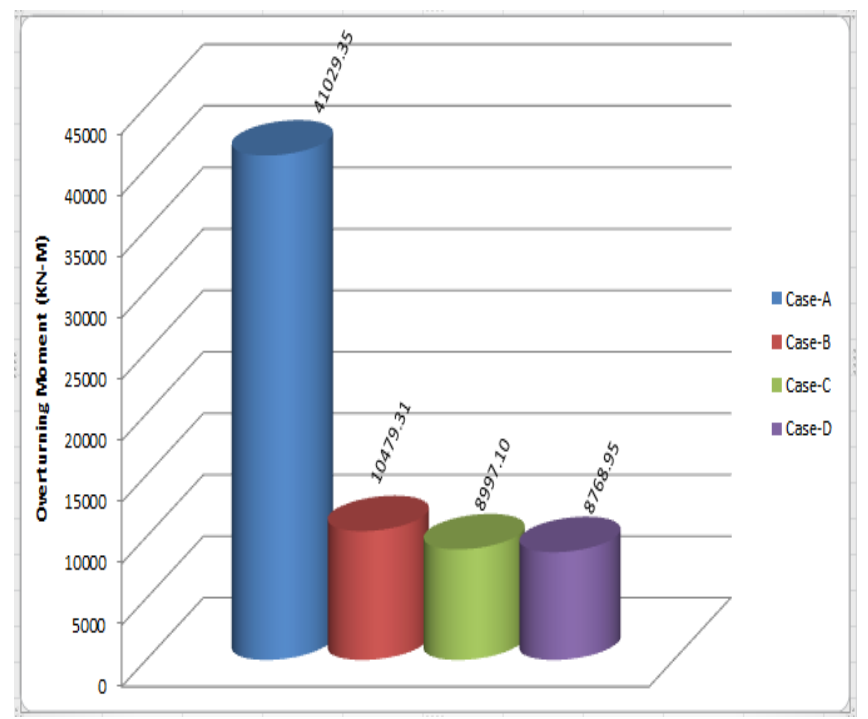

Fig27. Plot of Overturning Moment for Northbridge in 18 storey building

Table10. Overturning Moment (\%) for 12-storey w.r.t. CaseA (Fixed base)

\begin{tabular}{|l|l|l|l|}
\hline & Case-B & Case-C & Case-D \\
\hline El Centro & -2.11 & 27.68 & 29.91 \\
\hline Northbridge & 39.62 & 49.76 & 49.89 \\
\hline Kobe & 8.77 & 32.61 & 38.41 \\
\hline
\end{tabular}

Table11. Overturning Moment (\%) for 18-storey w.r.t. CaseA (Fixed base)

\begin{tabular}{|l|l|l|l|}
\hline & Case-B & Case-C & Case-D \\
\hline El Centro & 24.49 & 29.22 & 32.95 \\
\hline Northbridge & 40.04 & 50.60 & 55.45 \\
\hline Kobe & 44.70 & 49.13 & 51.40 \\
\hline
\end{tabular}

\section{CONCLUSIONS}

From the above analytical study following observations are noted

(1). Increase in fundamental time periods from $1.36 \mathrm{sec}$ to 4.5 sec is observed in 12 storey and 1.78 to 7.18 in Case-D.

(2). For the 12-Storey building, maximum reduction in storey drift was observed in Case-D. The average reduction was observed to be $81.47 \%$ as compared to Case-A (fixed base) and $20.73 \%$ reduction as compared to Case-B. In 18-Storey building, the drift is reduced by $83.28 \%$ reduction in Case-D as compared to Case-A and $21.43 \%$ as compared to base isolated Case-B.

(3). Maximum Reduction in base Shear was observed to be $76.56 \%$ and $80.77 \%$ in 12 and 18 storey respectively in Case$\mathrm{D}$ as compared to fixed base system Case-A. Also the maximum reduction was observed to be $2.8 \%$ and $13.86 \%$ as compared to base isolated Case-B for 12 and 18 storey structure repectively.

(4). Maximum Reduction in Acceleration is $81.50 \%$ and $73.78 \%$ in 12 and 18 storey respectively in Case-D as compared to fixed base system Case-A. Maximum reduction was observed to be of $15.16 \%$ and $4.2 \%$ as compared to base isolated Case-B for 18 storey structure.

(5). Maximum Reduction in over-turning moment is about $49.89 \%$ and $55.45 \%$ for 12 and 18 storey structure respectively in Case-D as compared to fixed base structure.

\section{REFERENCES}

[1]. Naeim, F., Kelly, J. M. - Design of Isolated Structures from Theory to Practice, John Wiley \& Sons, Inc.,

Canada, 1999

[2]. Jain S. K. Thakkar S. K., August 2004; Effect of superstructure stiffening in base isolated tall buildings, IE(I) Journal CV, Vol-85.

[3]. Hamidreza. F, Gholamreza. G. A., 2012, Nonlinear Response-History Analysis of Triple Friction Pendulum Bearings (TFPB), Installed Between stories, The 15thWorld Conference on Earthquake Engineering LISBOA.

[4]. Murakami K, Kitamura H, Ozaki H \& Teramoto. T, 2000 Design and analysis of a building with the middle-storey isolation structural system, The 12thworld Conference On Earthquake Engineering.

[5]. Xiangyun H, Zhou F, Wang S, Xuchai Luo, October 1217,2008 , Theoretical and experimental investigation on mid- 
storey seismic isolation system, The 14thworld Conference on Earthquake Engineering, Beijing, China.

[6]. Shiang-Jung Wang, Kuo-Chun Chang,Jenn-Shin Hwang, Jia-Yi Hsiao, Bo-Han Lee,YingChen Hung, 2012 Dynamic behavior of a building structure tested with base and midstorey isolation systems. Engineering Structures 42,(420-433), [7]. Shirayama A., Yamashita T, Ito S, Mukai Y, Baba K and Inoue Y,2004, Design proposal for controlling seismic behavior of inter-storey isolation building structures. The 13thWorld Conference on Earthquake Engineering Vancouver, Canada

\section{BIOGRAPHIES}

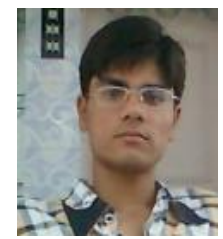

Amit J. Thoriya received his bachelor of engineering degree in civil engineering from Bhavnagar university in 2011. At present he is Final year student of Master's degree in Structural engineering from Marwadi Education Foundation Group of Institutions, Gujarat Technological University.

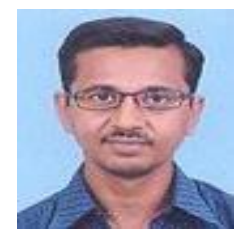

Mazhar A. Dhankot is Assistant Professor in Civil Engineering Department in Marwadi Education Foundation Group of Institutions. 